\title{
LYELL, JUKES, AND WHITAKER ON SURFACE-GEOLOGY.
}

To the Editor of the Grologioni Magazine.

Sik,-Since I last wrote very briefly on the origin of escarpments, you have admitted into your pages two articles, one by $\mathbf{M r}$. Whitaker, and one from Professor Jukes, which, were they to remain unnoticed, might leave the controversy too one-sided, more especially as the first-named author has spoken in very strong and persuasive terms (coupled with a grace and elegance which remind one of the illustrious Playfaix), which are calculated to mislead those who have not studied the other side of the question.

Lyell's Recantation.-Let me first call attention to a change of opinion in the great founder of inductive geology-Sir Charles Lyell, as announced by Mr. Whitaker. Ordinary coast-action, Sir Charles now believes, will not account for the parallelism of the Chalk and Greensand escarpments, or for both following the strike of the strata. But to reject coast-action as the main or primary cause of these escarpments is not entirely to give up the marine theory; for they may have originated in longitudinal cracks during axial elevation, and may afterwards have been deepened and widened, and their inner sides planed down by currents maintaining a general uniformity of direction, but at intervals deflected and reflected so as to hollow out the curvilinear "coves" by which the "capes" are separated." But suppose it could be shown that powerful currents, operating at a considerable, not " too great" a depth, are incapable of scooping out the depressions bounded by escarpments, it would not be more inconsistent with uniformity to suppose a cyclically-recurring intensification of the action of currents, caused by sudden upheavals of strata, than to admit " occasional strides, constituting breaks in the otherwise continuous series of (organic) changes." 3

Whitaker on Chalk Escarpments.-Mr. Whitaker and other subaërial geologists, though they have thrown difficulties in the way of the marine theory, have brought forward very few facts in support of their own views. The main force of what they have advanced lies in a few words-Because sea-coast action could not have done it, therefore it has been done by rain and frost. To state that a river sometimes flows near the base of an escarpment, coupled with the admission made by Messrs. Foster and Topley, and implied by $\mathbf{M r}$. Whitaker, that escarpments are not river-cliffs--that springs are often found at the base of escarpments-and that time will accomplish anything . . . cannot be regarded as evidences, unless it can be shown that these agents are now actually giving rise to phenomena similar to those requiring explanation. An escarpment is a steep, continuous slope. Continuity, both longitudinally and transversely, are its essential characteristics. Springs, at intervals, cause landslips which break this continuity, and therefore tend to destroy escarpments. Rain-streamlets (where they are not prevented by a covering

1 Groz. Mag. May, 1867.

2 See reference to escarpments under the Atlantic, ibid. p. 236.

3 Lyell's Antiquity of Man. 
of turf) furrow their faces, and tend to disfigure a smooth slope by a series of unsightly gutters. Frost cannot act effectively where an escarpment or slope does not already exist. Mr. Whitaker, to a certain extent, seems to admit this, when he speaks of "outliers" as "relics" of a former escarpment, and "inliers" as signs of a future escarpment. $\mathrm{He}$ invests subaërial agency with a power of beginning, by making something very unlike an escarpment, and ending by ruining an escarpment-the escarpment being only a stage of maximum development. Somewhat like Professor Babbage and his calculating engine, he makes his machinery capable of performing a miracle at a certain stage of its working, so as to give a result the opposite of that preceding and following. The fact would appear to be, that the action of the atmosphere, instead of forming a slope, tends directly to make a pre-existing slope less escarpmental. It has never been satisfactorily shown how, on a plane of marine denudation, the atmosphere could begin the work of escarpment-making.

Removal of Detritus.-Mr. Whitaker admits the absence of a talus from the face of Chalk escarpments, and states that the solid chalk comes up to the surface. But this is the case, not only, with the slopes but with the base of many Chalk escarpments; and it may be asked, if rain has washed away the soluble chalk, what has become of the insoluble flints? Is it reasonable to suppose that rain and frost, which act intermittingly, or by successive stages, can leave no sign of their action? Col. Greenwood (the father of modern subaërialism) admits that one rain leaves soil on its path to wait for the " next rain." The entire absence of detritus implies a cause equal in force and volume to a "sweeping" removal of the mass of chalk necessary to leave an escarpment. Uniformly-cut, and cleanly swept surfaces of chalk are common not only on the face and at the base of escarpments, but on the sides of gently swelling eminences, and on the level summits of table-lands, or "planes of marine denudation." There are many short Chalk escarpments, and parts of long escarpments, where the ground at the base is a plain, and where there is no stream to carry away the detritus which must result from the action of rain and frost, if they act at all. The streams in the neighbourhood of other escarpments are so sluggish, and choked with vegetation, that they tend rather to raise than lower the level of the area through which they flow. Mr. Whitaker admits that the formation of some escarpments is "delayed," and that rains, during a "former order of things," must have been more powerful than now. Why, then, not allow the advocate of marine denudation to suppose the action of currents formerly more energetic than at present? He appeals to the destruction of forests and other changes introduced by man as diminishing the fall of rain; but it is obvious that the denuding action of rain is much increased by the removal of trees, ${ }^{1}$ and the cultivation of the soil.

Inclined Escarpments.-Mr. Whitaker refers to escarpments, the base of which at one place is higher than the top at another; but

1 See Ljell on North American forests. 
such cannot be escarpments running along the strike in the same set of beds (according to Mr. Topley they cannot be escarpments at all), and if not due to the sea they cannot be the effect of atmospheric action-which "always follows the strike." Escarpments consisting of different beds at the lower from those at the upper end, can easily be explained by supposing the sea to have acted at different levels. A longitudinally-sloping cliff, of the same kind of rock throughout, might have been left by the sea during a gradual rise of the land, or it may have been unequally elevated after its formation. Subaërialists are not consistent in calling the latter supposition "groundless and unwarrantable," seeing that their theory (as explained by Messrs. Foster and Topley) involves a successive tilting up of the inner end of a valley to give " excavating power" to its stream.

Relation between Escarpments and Plains.-In the case of many Tertiary, Chalk, and Oolitic escarpments in Hampshire (especially in the vicinity of Southampton, where the parental relation between escarpments now formed by the sea, and inland escarpments on the same horizon, or at different parallel levels, is indisputable), Wiltshire, and Somersetshire, the top and base are continuous parallel planes. The level areas above and below will be admitted to be the work of the sea, and unless we can conceive of a coastless ocean, it is difficult to resist the belief that the face of the escarpment is likewise of marine origin. That the areas at the base of escarpments should be slightly inclined affords no presumption against the marine theory, as this is often the case with table-land "planes of marine denudation."

Weathered Escarpments.-Mr. Whitaker speaks of "a sea-cliff, weathered down into a slope with a talus," as distinct from an escarpment; but if the talus be a proof of the marine origin of a cliff, the escarpments of the Oolite, Lias, and all the older rocks must have been sea-cliffs. A striking instance is furnished by the - Cotswold escarpment, especially near Cheltenham and Gloucester, where a rocky cliff is for great distances concealed under a sloping talus, and where the atmosphere is still destroying a smoothlygrooved (especially near Crickley) and pitted sea-wall, which, at intervals, has resisted its action. The rocky limestone and millstone-grit escarpments of Derbyshire, Yorkshire and other counties, have their bases buried in accumulations of blocks, fragments, and rubbish (where they have not at intervals been swept clean, leaving a grassy platform or slope), which rains do very little to remove. The size of the fragments we see at the base of these cliffs (many of which are in situations where they could never have fallen) must be regarded as representing the size of the fragments which have been carried away, and indicating the power (nothing short of stormy waves) by which the transportation was effected. The socalled rain-wash, in many cases, must have come from a distance, and has not been furnished by a pluvial disintegration of the fragments on the spot, as is evident from its composition.

Assumed Distinctions between Escarpments and Sea-cliffs.-Mr. Whitaker institutes a series of distinctions between escarpments and 
sea-cliffs, most of which do not apply to the escarpments with which I am acquainted. I have only space for a few counter-statements.

1. The bottom of an escarpment does often keep to one level, and the top is often uneven.

2. Sea-cliffs do not always run straight through homogeneous rocks, but very often wind about in a succession of small capes and coves, which are included in "curves of large radius."

3. Among Archipelagos, such as the South of England must once have been, coasts are as often beachless as are the foot of escarpments. Shores suddenly sloping into deep seas, at a stationary level, or any kind of shores continuously rising, could never become covered with rounded shingle.

4. Sea-cliffs are not " backed by higher ground" in many parts of Archipelagos. Escarpments are often backed by higher groün.

Destruction of Sea-cliffs.-What Mr. Whitaker says about the atmosphere assisting the sea reads like special pleading for a favourite agent. It is as obvious that the sea makes its cliffs as it is that without the sea there would be no cliffs. At least two-thirds of the downfalling is the result of sheer gravitation through undermining. Many sea-cliffs for ages stand at the angle of gravitational repose. But as Mr. Whitaker admits that an immensely greater quantity of rock is denuded by the sea than by the atmosphere, it is not necessary that the relative claims of "the organ and the blower" should in this case be applied. The fact that the atmosphere does wear down and destroy sea-cliffs does not, however, seem quite compatible with the theory which assigns to the atmosphere a power of forming cliffs or escarpments.

Preservation of Ice-marks.--Mr. Whitaker attributes a deficiency of reasoning power to his opponents, while he himself uses one kind of reasoning in speaking of the sea, and another in reference to the atmosphere. If the preservation of glacial striæ under the sea, in some parts of the fjords of Norway, be an evidence against sea-action, their perpetuation on rock surfaces under the air must afford an equal proof of the inefficiency of rain. As regards the latter, it should be remembered that they often extend over great areas under a covering of soil, which could not be the case if "soil is rotted subsoil" (as Col. Greenwood calls it) on its way to a lower level.

Professor Jukes on the Avon Gorge.-In your MaGazINe (Oct., 1867,) this able geologist applies the "hard gorge and soft valley," theory of Col. Greenwood, to the neighbourhood of Bristol. But from his explanation, it is obvious that the theory requires the assistance of a sliding scale to make it fit different localities. Besides the Clifton gorge and the Bristol basin, there are at least ten hard gorges leading out of soft valleys (some of them perfectly flat-bottomed plains, with level-based escarpments, for instance, near Keynsham), which, from the relative nature of the rocks in which they occur, would appear to be inexplicable on the above theory. It may likewise be asked, if the limestone on both sides of the Clifton gorge escaped pluvial disintegration through being covered with newer rocks, how were the limestone ridges of the Western Mendips preserved, in Palæozoic times, when the Old Red Sandstone was in course of being 
eaten away so as to form the Vale of Winscombe? Professor Jukes implies that the sea, during the Glacial submergence, did no more to make valleys than a canal is made by the water it contains. I think the contrary can be shown by three facts: 1 . The rate at which the sea wears back its cliffs in many parts of the Bristol Channel may be fairly stated as, at least, a foot in a year. 2. The accumulations of drift in the midland and other counties (which exhibit no trace of being re-arranged Tertiary gravels, and which are only a part of what must have been excavated and removed to a distance,) would be sufficient to fill up many valleys, and obliterate many escarpments. 3. The duration of the glacial submergence may have been at least 50,000 years, probably much longer. During this period the sea must have converted many $\smile$ shaped vales into $\_$shaped plains, and may have eaten back many miles of the eastern side of the Severn valley so as to leave the great Cotswold escarpment.

D. Mackintosh.

P.S.-I see that the number of the Quart. Journ. Geol. Soc. for the present month (Nov.) contains several important articles in favour of marine denudation.

\section{RESEARCHES IN BRITISH MINERALOGY.}

\section{To the Editor of the Geologicax Magazine.}

Sin,-Mr. David Forbes in a paper in the November number of the London and Edinburgh Philosophical Magazine, under the title of " Researches in British Mineralogy," gives the results of an analysis made by himself of a silver-fahlerz from the Fox-dale silver-lead mine, in the Isle of Man, and in the introductory paragraph he says, "Although the cupriferous tetrahedrite (occasionally containing traces of silver) has been found in small quantities at various localities in both England, Scotland, Ireland, and Wales, there is no analysis of true silver-fahlerz or polytelite, or even occurrence of the mineral itself recorded, as far as the author has been enabled to ascertain." From this I infer that Mr. Forbes will be surprised to learn that silver-fahlerz has already been found in quantity in this country and mined for the silver it contains. For several years past it has been raised and sold as a silver and copper ore at the Silver-vein Mine, near Lostwithiel, Cornwall. Indeed this mine is, and has been worked solely for the silver-fahlerz, no other ore being found in any useful quantity. The lode (for it is not found in "pockets" only) runs about 43 degrees east of north and west of south. Its width appears to have varied considerably, but at the present time it is about four feet wide. It traverses the "Killas" or clay-slate of the district and, so far, the ore has become richer in silver as the depth increases. I know of no accurate analysis having been made of this ore, so that Mr. Forbes would be doing further good service to British Mineralogy if he would take such a work in hand. From eight assays made by Messrs. Johnson and Johnson and others, some years since, the average yield of silver was $68 \frac{1}{2}$ 